\author{
Joanna Helios \\ Uniwersytet Wrocławski \\ joanna.helios@uwr.edu.pl \\ Wioletta Jedlecka \\ Uniwersytet Wrocławski \\ wioletta.jedlecka@uwr.edu.pl
}

\title{
Diagnoza i ochrona dziecka z traumą rozwojową w polskim systemie oświatowym
}

\section{Summary \\ Diagnosis and protection of the child with traumatic development in the Polish educational system}

The aim of this article is to diagnose the symptoms of disorders and functioning of children at risk and traumatic development in the Polish educational system, as well as to identify possible legislative solutions related to appropriate educational and therapeutic activities and to safeguard the educational rights of these children. In educational law, there are legal solutions that provide the opportunity to organize for a child with more favorable conditions in the education system based on the value of educational equality.

Słowa kluczowe: trauma rozwojowa, dysocjacja, prawo oświatowe, prawa dziecka

Keywords: developmental trauma, dissociation, educational law, children's rights

\section{Wprowadzenie}

Celem niniejszego artykułu jest rozpoznanie objawów zaburzeń i funkcjonowania dzieci z grupy podwyższonego ryzyka oraz objawami traumy rozwojowej w polskim systemie oświatowym, a także wskazanie możliwych rozwiązań legislacyjnych związanych z odpowiednimi działaniami wychowawczo terapeutycznymi i zabezpieczeniem praw edukacyjnych tych dzieci. Do grupy podwyższonego ryzyka zaliczamy dzieci z rodzin adopcyjnych i zastępczych. Zaburzenia posttraumatyczne możemy w uproszczeniu podzielić na dwie grupy. Takie, które są następstwem pojedynczego zdarzenia (np. wypadku, napadu, katastrofy) i te, które wynikają z chronicznego nadużywania lub zaniedbania, czy innych skumulowanych i długotrwałych czynników. Mówimy wtedy o traumie kompleksowej lub skumulowanej. W wypadku dzieci, szczególnie trauma drugiego typu ma poważne następstwa rozwojowe. W związku z tym w opracowaniu posługujemy się określeniem 
„trauma rozwojowa”. Obraz kliniczny dziecka po doświadczeniu traumy ująć można w czterech podstawowych kategoriach: A. Niestabilność uczuciowa i fizjologiczna; B. Zaburzenia w zakresie uwagi i zachowania; C. Typowe tzw. intruzywne zaburzenia PTSD (zespołu stresu pourazowego)- wspólne tak dla dorosłych jak i dla dzieci; D. Zaburzenia samooceny i relacji (w tym przywiązania). U dzieci kluczowym następstwem traumy jest zaburzona autoregulacja. Ta z kolei przekłada się na zakłócenia w funkcjonowaniu organizmu. Zaburzenia posttraumatyczne są przede wszystkim problemem zdrowotnym, a nie jedynie wychowawczym (www.nslt.pl/dostęp: 5.11.2017). Kiedy ofiarą jest dziecko i trauma ma charakter chroniczny oraz, dodatkowo, gdy sprawcą jest osoba znana lub bliska, brakuje niestety skutecznych buforów chroniących przed skutkami traumy. Traumy złożone, a wśród nich tzw. traumy zdrady, wywołują długofalowe konsekwencje w postaci chronicznych zaburzeń PTSD, czy szerzej Complex PTSD (Zdankiewicz-Ścigała 2017: 19-22). Sama dysocjacja (Jedlecka 2014: 97 i n.) jest naturalną częścią obrony psychiki przed potencjalnie niszczącym wpływem traumy. Jest „figlem”, który psychika płata sama sobie. Pozwala żyć dalej dzięki oddzieleniu przeciążającego psychikę doświadczenia i umieszczeniu go w różnych częściach ciała i umysłu, a szczególnie w nieświadomych aspektach ciała i umysłu. Oznacza to, że normalnie zjednoczone elementy świadomości nie mogą podlegać procesowi integracji (Kalsched 2015: 31-32).

Sfera prawna jest dość istotna w odniesieniu do dzieci z traumą rozwojową, gdyż dzięki niej możliwe jest dostosowanie systemu szkolnego do specyficznych potrzeb tych dzieci, co ma wspomóc proces ich zdrowienia (Helios, Jedlecka 2015). W prawie oświatowym istnieją rozwiązania prawne, które dają możliwość zorganizowania dziecku z traumą bardziej sprzyjające warunki w systemie edukacyjnym w oparciu o wartość jaką jest równość edukacyjna.

\section{Diagnoza i funkcjonowanie dziecka z traumą rozwojową}

Wiele rodzin zastępczych i adopcyjnych boryka się z trudnościami wynikającymi z opieki nad dzieckiem skrzywdzonym w przeszłości, czyli dotkniętym traumą rozwojową. Te trudności powodują czasem poważne problemy w funkcjonowaniu rodziny, a nawet jej rozpad (Kiwer 2011: 1). Do powstawania trudności przyczyniają się także stereotypy, funkcjonujące w polskim społeczeństwie, wedle których dziecko przysposobione w niemowlęctwie nie zna innego domu niż ten w którym wyrosło, nie wyobraża sobie innych rodziców niż ci, którzy je wychowują. Można nim pokierować bez większych trudności, upodobni się ono bardziej do przysposabiających, bo jak każde dziecko naśladuje mimikę, ruchy, sposób bycia najbliższych, a przede wszystkim, co jest najważniejsze, nie powstaną w jego systemie nerwowym, psychice i rozwoju ogólnym zmiany, będące konsekwencją braku indywidualnej opieki w okresie przed adopcją (Bielicka i in. 1996: 64). Takie podejście nie uwzględnia najnowszych osiągnięć neurobiologii, chociażby w zakresie badania mózgu i zjawisk dysocjacyjnych (Bremner 2009). Na skutek niezrozumienia dynamiki zmian zachodzących u takich dzieci, o pod- 
łożu neurobiologicznym, też różnorakich zaburzeń związanych z ich traumami, wobec dzieci z traumą rozwojową stosowane są środki przymusu (Goetz 2011: 10 i n.). Dzieci przebywające $\mathrm{w}$ opiece zastępczej i w rodzinach adopcyjnych mogą cierpieć na zaburzenia więzi, które są ściśle związane z traumą rozwojową. Charakterystycznym zaburzeniem więzi dla tej grupy dzieci jest RAD (Reactive Attachment Disorder). G. Keck i R. Kupecky (2010:55) wymieniają szereg objawów charakterystycznych dla dzieci z RAD, np. powierzchownie ujmujące i czarujące zachowanie, bezkrytyczna sympatia wobec obcych, brak uczuć w stosunku do rodziców, słaby kontakt wzrokowy itp. K. Kiwer (2011: 6) podkreśla, że w procesie wychowania dziecka z traumą rozwojową nieskuteczne okazują się wszelkie systemy oparte na karaniu, wywołując zazwyczaj efekty odwrotne od zamierzonego. U dzieci z RAD zachowania negatywne, podlegające karze są powtarzane. Gdy katalog kar się wyczerpie, opiekun staje się bezradny. Stosowanie środków przymusu zwiększa u takich dzieci lęk i prowadzi do zachowań agresywnych lub autoagresywnych. L. Drozdowski (2011: 7) zauważa, że dzieci cierpiące na zaburzenia posttraumatyczne bardzo dobrze podporządkowują się narzędziom stosowanym w ramach systemu państwowego, instytucjonalnego czy edukacyjnego. Jednakże jest to podporządkowanie zgoła pozorne. Dzieci z zaburzeniami posttraumatycznymi przystosowały się już we wczesnym dzieciństwie. Mają mózg ukształtowany przez dysfunkcje w relacji z matką / opiekunem lub patologiczne doświadczenia. Mózg tych dzieci przywoływany Autor określa jako „mózg przetrwania”. (Drozdowski 2011: 8). Wskazywane są różnice pomiędzy zaburzeniami występującymi u dzieci, które doświadczyły przemocy czynnej i które były zaniedbywane (przemoc bierna). Dzieci zaniedbywane nie miały szansy nauczyć się regulowania własnych stanów emocjonalnych. Z kolei jeżeli dziecko doświadczyło przemocy, jego układ limbiczny charakteryzuje się ciągłą nadreaktywnością. Takie dziecko ma mniejsze umiejętności radzenia sobie ze stresem, które będą rzutowały na sposób jego funkcjonowania również w dorosłym życiu. W ich przypadku różnego rodzaju bodźce, odbierane zwykle podświadomie, stają się wyzwalaczem gwałtownych reakcji lub dysocjacji (Bartnikowska 2017).W związku z tym opiekun zastępczy czy rodzic adopcyjny musi być przygotowany na komplikacje związane z opieką i wychowaniem, musi się także liczyć z dodatkowymi trudnościami, związanymi z wcześniejszymi negatywnymi i bolesnymi przeżyciami dziecka w rodzinie biologicznej. Typowe komplikacje to trudności adaptacyjne, niedostosowanie społeczne, zaburzenia osobowości, braki dydaktyczno-wychowawcze. Dziecko osamotnione obarczone jest traumatycznymi wydarzeniami wynikającymi z zaniedbania, odrzucenia czy poczucia winy z powodu sytuacji w jakiej się znalazło. Często silnie przeżywa poczucie straty bliskich osób i ważnych miejsc, z którymi było związane, nie rozumie dlaczego zostało wyrwane ze swojego środowiska (Ruszkowska 2014: 14). Zadanie polegające na opiece nad dziećmi z zaburzeniami więzi oznacza podejmowanie świadomych terapeutycznych decyzji rodzicielskich i ciągłego skupiania się na głębszym znaczeniu zachowania dzieci. Chodzi o to, żeby reagować na przyczyny, odpowiadać na potrzeby i motywy, które kierują dziećmi (Brooks 2017: 236-248). Poważnym proble- 
mem jest brak rozumienia traumy rozwojowej i zaburzeń dysocjacyjnych przez rodziców, opiekunów, wychowawców, także instytucje, w tym szkoły, których celem jest dbanie o dobro dziecka. Dzieci przebywające w placówkach wykazują problemy w zakresie przystosowania do regulaminów, systemu opieki, wychowania i edukacji. W przekonaniu L. Drozdowskiego (Weigl 2011:104 i n.) pierwszym krokiem powinno być „oswojenie” rozumiane jako zbudowanie przywiązania i bazującego na nim zaufania a nie posłuszeństwo. Dopiero później jest terapia, rehabilitacja, edukacja, dyscyplina (Drozdowski 2009: 91). Trauma rozwojowa i związana z nią dysocjacja wpływa na proces uczenia się oraz kompetencje społeczne. Hormony stresu, które przygotowują mózg do szybkiego reagowania, z czasem niszczą zdolności mózgu do normalnego uczenia się. Dzieci po urazach mają trudności w nauce. Są przesadnie czujne i nadmiernie pobudzone. Problemy te często są błędnie diagnozowane jako ADHD (zespół nadpobudliwości psychoruchowej z zaburzeniami koncentracji uwagi). Dzieciom z traumą rozwojową brakuje umiejętności skupienia uwagi. W nauce na ogół są sztywne, mało elastyczne. Często mają kłopoty ze snem, więc w szkole sprawiają wrażenie marudnych i nieuważnych. Jeżeli nawrót traumatycznych zdarzeń ogarnie dziecko w szkole, może ono wpaść w stan dysocjacji i całkowicie zgubić główny temat lekcji. Kiedy dzieci zaczyna ogarniać paniczny lęk, maleje ich umiejętność opowiedzenia o tym, co dzieje się $\mathrm{w}$ ich wnętrzu. Bywa, że stają się agresywne w reakcji na ogromny ładunek energii wywołany przygotowaniem się do walki lub ucieczki, który niesie ze sobą lęk. Dzieci te potrzebują najstaranniej przemyślanej struktury, wprowadzanej w życie w jak najbardziej opiekuńczy i troskliwy sposób. Zamiast tego otrzymują często bardzo mało opiekuńczości w systemie szkolnym, który nacechowany jest surowym i ostrym podejściem. Dzieci po urazie potrzebują spokojnego, konsekwentnego i opiekuńczego podejścia, by mogły uczyć się jak najlepiej. Dzieci z traumą mają duże trudności z ustaleniem chronologii zdarzeń. Mają też problemy z zapamiętywaniem. Bezpośrednio po urazie nie powinny uczestniczyć w stresujących dla nich zajęciach szkolnych (Gray 2010: 105109). W przypadku dzieci z traumami rozwojowymi i zaburzeniami dysocjacyjnymi za szczególnie istotne należy uznać współdziałanie rodziny i szkoły. Ważny jest tutaj element nawiązania przez dziecko więzi z nauczycielami. W kontakcie zarówno z nimi, jak i z rówieśnikami może ono odtwarzać pierwotną - patologiczną, ale znaną mu - relację opartą na zaniedbywaniu lub przemocy. Istotne w tym wypadku jest zrozumienie tego mechanizmu, akceptowanie dziecka $\mathrm{z}$ tego typu objawami oraz wspieranie go w zmienianiu postępowania. Empatia i zrozumienie, prawidłowa interpretacja zachowań dziecka i jego potrzeb są kluczem do sukcesu. Nauczyciel dyscyplinujący i karzący uzyskuje gorsze rezultaty niż taki, który dba o prawidłową relację z dzieckiem. Takie postępowanie nauczyciela, nastawione na właściwą interakcję, może się kłócić z powszechnie przyjętymi standardami, ponieważ zachowanie dziecka pozornie wydaje się rozmyślnie złośliwe. Dlatego ważne jest zaakceptowanie faktu, że zaburzenia więzi, trauma rozwojowa i dysocjacja wymaga niestandardowego podejścia ze strony nauczyciela do ucznia (Bartnikowska 2013:30). Rozpoczęcie nauki w szkole uznawane jest za sytuację trudną 
dla dziecka. Związane jest to $\mathrm{z}$ wejściem w nowe role społeczne, w tym też $\mathrm{z}$ byciem ocenianym, z przymusem spędzania czasu w ławce, hamowaniem naturalnej aktywności i ciekawości świata, koniecznością podporządkowania się określonym regułom. Przystosowanie do szkoły oznacza: udział w pracy klasy, umiejętność koncentracji uwagi, samodzielność, wydajność, powstrzymywanie się od zachowań zakłócających pracę. Adaptacja szkolna zakłada odpowiedni poziom rozwoju fizycznego, poznawczego, emocjonalnego i społecznego. Rozwój emocjonalny i społeczny są niezwykle istotne z punktu widzenia zaburzeń dysocjacyjnych albowiem zdolności adaptacyjne dziecka z zaburzeniami dysocjacyjnymi są ograniczone, co przekłada się na jego funkcjonowanie w środowisku szkolnym. Takie dziecko nie przystosowuje się do warunków szkolnych w sposób zdrowy, ale przełącza się na znany mu tryb „przetrwania”, uruchamiający mechanizmy dysocjacyjne. Włączając mechanizm dysocjacyjny dziecko wyłącza, częściowo lub całkowicie, percepcję bodźców z otoczenia, odłącza myślenie od emocji (Bartnikowska i in. 2013: 119). W systemie szkolnym dzieci z traumą rozwojową nie są w stanie dostać troskliwej opieki, która będzie dostosowana do poziomu ich rozwoju, ale nie do wieku metrykalnego, z którym długo jeszcze nie będzie się ona zgadzać. Najlepszym rozwiązaniem są pozytywne opiekuńcze relacje $\mathrm{z}$ bezpiecznymi rówieśnikami, godnymi zaufania nauczycielami, okazującymi miłość opiekunami, co działa lecząco zwłaszcza na dzieci porzucone i zaniedbane, którym brakowało stymulacji neuronalnej do budowy zdolności przywiązania i relacji z innymi (Perry, Hambrick 2017).

\section{Ochrona dziecka z traumą rozwojową w polskim systemie oświatowym}

Literatura prawnicza na temat ochrony praw dziecka jest szeroka i niezwykle zróżnicowana (Balcerek 1998). Prawa dziecka są pojęciem z kategorii praw człowieka i wynikają z godności i niepowtarzalności dziecka jako jednostki ludzkiej. W skład praw dziecka wchodzi prawo do nauki. Jeżeli dziecko ma prawa, to obowiązkiem władzy państwowej jest zapewnienie realizacji tychże praw (Łopatka 2000:44). Stopniowo w debacie publicznej i naukowej można było obserwować tendencje przypisujące edukacji rolę jednej z podstawowych przesłanek do realizacji pozostałych praw i wolności człowieka. W edukacji zaczęto upatrywać dobra społecznego, perspektywy możliwości rozwoju potencjału jednostki i całego społeczeństwa (Leś, Kozak 2015: 16-17). Zadaniem polityki społecznej państwa jest zapewnienie równego dostępu do edukacji wszystkim jednostkom na każdym szczeblu kształcenia. Równość szans edukacyjnych stanowi jeden z priorytetów oświatowych wielu krajów w Europie i na świecie (Butarewicz-Głowacka 2015:102). Pomimo istnienia odpowiednich aktów prawnych, zarówno międzynarodowych (Konwencja o prawach dziecka), jak i krajowych uczniowie skarżą się na „nierówne traktowanie” z powodu statusu ucznia (dobry - słaby) lub statusu społecznego lub materialnego rodziców (Czyż 1996:87). Równość szans wymaga równości szans edukacyjnych. Jednym z głównych założeń reformowanego systemu kształcenia stało się jak najwcześniejsze dotarcie do dziecka, rozpoznanie jego rozwoju poprzez zorganizowaną działalność psychologiczno 
- pedagogiczną i edukacyjną (Wejner 2003: 127). Z równością związane jest ściśle prawo do nauki. Należy ono do tzw. drugiej kategorii praw człowieka. Oznacza ono prawo każdego człowieka do kształcenia się we wszystkich jego postaciach, zakładając, że edukacja otwiera każdej jednostce możliwości intelektualne do korzystania ze swoich praw. Prawo do nauki uzyskało rangę konstytucyjną. Definicja prawa do nauki została zawarta w Konwencji w sprawie zwalczania dyskryminacji w dziedzinie oświaty z 1960 r. (Dz. U. z 17 listopada 1964, nr 40, poz. 268), ratyfikowaną przez Polskę w 1964 r. Zgodnie $\mathrm{z}$ art. 1 Konwencji zabroniona jest wszelka dyskryminacja w dostępie do nauki ze względu na rasę, kolor skóry, płeć, język, wyznanie, przekonania polityczne lub jakiekolwiek inne, narodowość lub pochodzenie społeczne, sytuację materialną lub urodzenie (Urbaniak 2009: 135-136). Adresatem standardów ochrony praw dziecka, wynikających z reguł międzynarodowych, europejskich i wewnętrznych jest także dziecko z traumą rozwojową.

Jednym z aktów prawnych, który może służyć jako standard ochrony dzieci z traumą rozwojową, jest rozporządzenie MEN z dnia 28 sierpnia 2017 r. zmieniające rozporządzenie w sprawie zasad udzielania i organizacji pomocy psychologiczno - pedagogicznej w publicznych przedszkolach, szkołach i placówkach (Dz. U. 2017, poz. 1643). Zgodnie z punktem 1 powołanego rozporządzenia: „Pomoc psychologiczno-pedagogiczna udzielana uczniowi w szkole i w placówce polega na rozpoznawaniu i zaspokajaniu indywidualnych potrzeb rozwojowych i edukacyjnych ucznia i czynników środowiskowych wpływających na jego funkcjonowanie w szkole i placówce, w celu wspierania potencjału rozwojowego ucznia i stwarzania warunków do jego aktywnego i pełnego uczestnictwa w życiu szkoły i placówki oraz w środowisku społecznym". Ważny jest punkt 2 cytowanego aktu, który wskazuje, iż potrzeba objęcia ucznia pomocą psychologiczno - pedagogiczną w szkole wynika w szczególności: 9) z sytuacji kryzysowych lub traumatycznych. Można a priori wnioskować, iż dziecko z traumą rozwojową jest uczniem ze specjalnymi potrzebami edukacyjnymi (Czupajło, Dudek 2010: 22 i n.). W warunkach „chronionych”, przystosowanych do potrzeb i możliwości dziecka, dzięki możliwości umieszczenia dziecka z traumą rozwojową w klasie terapeutycznej, ma ono szansę na zdrowienie (Bartnikowska i in. 2013: 120).

Drugim środkiem ochrony dzieci z traumą rozwojową jest indywidualne nauczanie. Nieobowiązujące już Rozporządzenie Ministra Edukacji Narodowej z dnia 28 sierpnia 2014 r. $w$ sprawie indywidualnego obowiazkowego rocznego przygotowania przedszkolnego dzieci i indywidualnego nauczania dzieci i młodzieży (Dz. U. 2014, poz. 1157) dawało możliwość przeprowadzania nauczania indywidualnego w szkole i w domu ucznia. Intencją historycznego prawodawcy było dostosowanie do potrzeb rozwojowych i edukacyjnych oraz możliwości psychofizycznych ucznia zajęć edukacyjnych. Dyrektor szkoły, na wniosek nauczyciela prowadzącego zajęcia indywidualnego nauczania, mógł zezwolić na odstąpienie od realizacji niektórych treści nauczania objętych obowiązkowymi zajęciami edukacyjnymi, stosownie do możliwości psychofizycznych ucznia oraz warunków w miejscu, w którym są organizowane zajęcia indywidualnego nauczania. Nowe Rozporządzenie MEN z dnia 28 sierpnia 2017 r. zmieniajace rozporzadzenie w sprawie indywi- 
dualnego obowiazkowego rocznego przygotowania przedszkolnego dzieci i indywidualnego nauczania dzieci i młodzieży (Dz. U. 2017, poz. 1656) zrezygnowało z nauczania indywidualnego w szkołach i przedszkolach. Nauczanie indywidualne ma się odbywać w miejscu pobytu ucznia, w szczególności w domu rodzinnym (§ 5). Zdaniem MEN ta forma nauczania przeznaczona jest tylko dla dzieci i młodzieży, których stan zdrowia „znacznie utrudnia lub uniemożliwia” realizację obowiązku nauki. Według oceny MEN nauczanie indywidualne w szkołach i placówkach obejmowało także uczniów sprawiających trudności wychowawcze i wykazujących niedostosowanie społeczne. W wielu przypadkach stan dzieci z traumą rozwojową „znacznie utrudnia lub uniemożliwia” uczęszczanie do szkoły (np. choroby somatyczne, zaburzenia snu). Jednakże duża część dzieci z traumą rozwojową, na skutek zaburzeń więzi, jest klasyfikowana jako uczniowie sprawiający trudności wychowawcze i wykazujący niedostosowanie społeczne. Zatem istnieje realna obawa, że zmiany w zakresie nauczania indywidualnego mogą wykluczyć część dzieci z traumą rozwojową z możliwości realizacji nauki w tej formie, tym samym pozbawiając ochrony ich praw.

Trzecim środkiem, który może zapewnić ochronę dzieci z traumą rozwojową jest eksperyment pedagogiczny, uregulowany w art. 45 ustawy z dnia 14 grudnia 2016 r. Prawo oświatowe (Dz. U. z 2017 r., poz. 59). Eksperyment pedagogiczny polega na modyfikacji istniejących lub wdrożeniu nowych działań w procesie kształcenia, przy zastosowaniu nowatorskich rozwiązań programowych, organizacyjnych, metodycznych lub wychowawczych, w ramach których są modyfikowane warunki, organizacja zajęć edukacyjnych lub zakres treści nauczania. W związku z tym może zostać wykorzystany do ochrony dzieci $\mathrm{z}$ traumą $\mathrm{w}$ szkole poprzez dostosowanie programów nauczania do ich potrzeb i możliwości, a przez to uczynić naukę szkolną wielokrotnie efektywniejszą i minimalizującą stres związany z zaburzeniami traumatycznymi.

I wreszcie czwarta możliwość ochrony praw dzieci z traumą rozwojową, czyli edukacja domowa (Helios 2014: $180 \mathrm{i}$.), często wykorzystywana w procesie terapeutycznym, z uwagi na fakt, iż ze względu na wielość oddziaływań terapeutycznych, realizacja obowiązku szkolnego poprzez regularne uczęszczanie do szkoły nie jest możliwa. Przywoływana już ustawa Prawo oświatowe w art. 37 stanowi, iż na wniosek rodziców dyrektor odpowiednio publicznego lub niepublicznego przedszkola, szkoły podstawowej i szkoły ponadpodstawowej, do której dziecko zostało przyjęte, może zezwolić, w drodze decyzji, na spełnienie przez dziecko obowiązku szkolnego, poza przedszkolem, oddziałem przedszkolnym w szkole podstawowej lub inną formą wychowania przedszkolnego i obowiązku szkolnego lub obowiązku nauki poza szkołą. Zezwolenie może być wydane przed rozpoczęciem roku szkolnego albo w trakcie roku szkolnego. Nowa ustawa wprowadziła pewne zmiany w zakresie edukacji domowej. Dotychczas rodzice edukujący domowo mieli możliwość wyboru dowolnej szkoły, do której dziecko będzie zapisane i w której będzie zdawało coroczne egzaminy. Obecnie nastąpiła rejonizacja - czyli brak możliwości wyboru szkoły spoza województwa (art. 37. ust. 2 pkt1). 


\section{Wnioski końcowe}

Na podstawie przeprowadzonych rozważań uważamy, że po pierwsze, równość edukacyjna $\mathrm{w}$ odniesieniu do dzieci z traumą rozwojową powinna być realizowana za pośrednictwem standardów wynikających z aktów chroniących prawa dziecka; po drugie, polski system prawa oświatowego daje określone instrumenty prawne, które umożliwiają realizację obowiązku szkolnego przez dzieci z traumą rozwojową. Jednakże ich właściwe wykorzystanie wymaga współpracy pedagogów, psychologów, nauczycieli, lekarzy i prawników. Niestety intencja prawodawcy na skutek błędnej interpretacji wskazanych przez nas przepisów, nie zawsze jest w sposób prawidłowy odczytywana przez specjalistów, tym samym powodując wykluczenie pewnej grupy dzieci z systemu edukacyjnego, co jest sprzeczne z gwarantowanym przez Konstytucję prawem do nauki.

\section{Literatura}

Balcerek M. (1988), Międzynarodowa ochrona dziecka, Warszawa, Wydawnictwo WSiP.

Bartnikowska U. (2013), Zerwane więzi - dziecko z syndromem RAD - nowy obszar działań pedagogów specjalnych, „Człowiek - Niepełnosprawność - Społeczeństwo”, 1 (19).

Bartnikowska U. (2013), Z doświadczeniami „przetrwania” - w szkole. O adaptacji szkolnej dysocjujacego dziecka, W: Drozdowski L. i in., Dysocjacja - terra incognita? - od adaptacji do patologii. Zaburzenia dysocjacyjne u dzieci po traumach, „Annals of Diagnostic Peadiatric Pathology", 3-4 (17).

Bartnikowska U., Zranione dziecko - czy wystarczy tylko je kochać? Perspektywa rodzin adopcyjnych i zastępczych, polskadzieciom.home.pl/nslt/Zranione_Dziecko.pdf. (dostęp: 16.03.2017).

Bielicka J., Stelmachowski A., Sztekiel E. (1996), O przysposobieniu (adopcji) dzieci mówią: lekarz, działacz spoleczny, prawnik, Warszawa, Wydawnictwo Prawnicze.

Bremner JD (2009), Neurobiology of Dissociation: A View from Trauma Field. W: PF Dell, JA O'Neil (red.) Dissociation and the Dissociative Disorders, DSM-V and Beyond, Routledge, New York, London.

Brooks J. (2017), Mogło być inaczej. Prawdziwa historia rodziców, którzy zrobili wszystko, by ocalić córkę, przełożyła J. Szajkowska, Warszawa, Wydawnictwo Prószyński i S-ka.

Butarewicz-Głowacka A. (2015), Nie(równość) szans edukacyjnych uczniów cudzoziemskich w polskiej szkole - komunikat z badań, „Parezja”, 2 (4), Z Warsztatu Badawczego.

Czupajło T., Dudek M. (2014), Razem i osobno. Edukacja wczesnoszkolna. Dzieci ze specjalnymi potrzebami edukacyjnymi. Klasa I, II, III, Warszawa, Wydawnictwo Stowarzyszenie Nauczycieli Edukacji Początkowej.

Czyż E. (1996), Prawa uczniów w szkole. Reportaż z badań, Warszawa, Helsińska Fundacja Praw Człowieka.

Drozdowski L. (2009), System opieki nad dzieckiem i rodzina - część III, „es.O.es”, 2.

Drozdowski L. (2011), Dziecko w podróży przez system. Procesy dysocjacyjne u dzieci po traumach, „Niebieska Linia”, 3 (74).

Drozdowski L. (2011), „, T” dziecko z doświadczeniami kompleksowej traumy, W: L. Drozdowski, B. Weigl (red.), Rodzinne domy dziecka - opieka, wychowanie, terapia, Warszawa, Wydawnictwo Orlenu. 
Gray D.D. (2010), Adopcja i przywiązanie. Praktyczny poradnik dla rodziców, przekład M. Lipińska M. i in., Sopot, Wydawnictwo GWP.

Goetz M. (2011), Trauma z empatii. O wtórnym zespole stresu pourazowego, „Niebieska Linia”, 2 (73).

Helios J. (2014), Edukacja domowa - kilka uwag w kontekście dyskursu o edukacji demokratycznej, „Filozofia Publiczna i Edukacja Demokratyczna”, 2 (3).

Helios J., Jedlecka W. (2015), Dysocjacja jako hard case w systemie prawa, Wrocław, Wydawnictwo E - monografie.

Jedlecka W. (2014), Pojęcie „dysocjacji” - zagadnienia podstawowe, „Filozofia Publiczna i Edukacja Demokratyczna", 2 (3).

Kalsched D. (2015), Wewnętrzny świat traumy. Archetypowe obrony Jaźni, przekład Małgorzata Kalinowska, Poznań, Wydawnictwo ZYSK I S-KA.

Keck G., Kupecky R. (2010), Wychowanie zranionego dziecka. Pomoc rodzinom adopcyjnym $w$ zdrowieniu i rozwoju, Warszawa, Wydawnictwo Mraciniewski Services.

Kiwer K. (2011), RADosne dziecko czy nieletni przestepca?, „Niebieska Linia”, 3 (74).

Jas M., Jarosińska M. (2010), Specjalne potrzeby edukacyjne dzieci i młodzieży. Prawne ABC dyrektora przedszkola szkoły i placówki, Warszawa, Wydawca Ministerstwo Edukacji Narodowej.

Leś T., Kozak M. (2015), Filozoficzno-prawne aspekty uzasadniania prawa do równości w edukacji, „Parezja”, 2 (4), Studia i Eseje.

Łopatka A. (2000), Dziecko - jego prawa człowieka, Warszawa, Wydawnictwo Biblioteka Sejmowa.

Perry D.B., E. Hambrick, Neurokonsekwencyjny Model Terapii (NMT), przekład R. Tulo Waśkiewicz, stronyocalenia.pl/attachments/article/123/Perry_NeurosekwencyjnyModelTerapii.pdf (dostęp: 20.03.2017).

Ruszkowska M. (2014), Dziecko krzywdzone w opiece zastępczej, „Niebieska Linia”, 3 (92).

Urbaniak M. (2009), Konstytucyjne wolności i prawa socjalne oraz ekonomiczne w Polsce $i$ we Włoszech. Analiza prawno porównawcza, Toruń, Wydawnictwo Adam Marszałek.

Wejner T. (2003), Wyrównywanie szans edukacyjnych uczniom ze specyficznymi trudnościami w uczeniu się, W: Polska dla Dzieci. Ogólnopolski Szczyt w sprawach Dzieci Warszawa 23-24 maja 2003 r. Materiały i dokumenty, Warszawa, Wydawnictwo Rzecznik Praw Dziecka.

Zdankiewicz-Ścigała E. (2017), Aleksytymia i dysocjacja jako podstawowe czynniki zjawisk potraumatycznych, Warszawa, Wydawnictwo Naukowe SCHOLAR, Uniwersytet SWPS. 